\title{
Effect of Dual Blockade of Renin-Angiotensin System on Proteinuria
}

\author{
Eqerem Hasani $^{{ }^{*}}$, Alma Idrizi ${ }^{2}$, Myftar Barbullushi $^{2}$ \\ ${ }^{1}$ Service of Cardiology, UHC "Mother Teresa", Tirana, Albania; '2 Service of Nephrology, UHC "Mother Teresa", Tirana, \\ Albania
}

\author{
Citation: Hasani $E$, Idrizi $A$, Barbullushi $M$ \\ Effect of Dual Blockade of Renin-Angiotensin \\ System on Proteinuria. OA Maced J Med Sc \\ 2013 Dec 15; 1(1):18-20 \\ http://dx.doi.org/10.3889/oamjms.2013.004 \\ Key words: dual blockade; renin-angiotensin \\ system; angiotensin-converting enzyme \\ $\begin{array}{lll}\text { system; angiotensin-converting enzyme } & \\ \text { inhibitor; angiotensin receptor blocker; }\end{array}$ \\ proteinuria. \\ "Correspondence: Eqerem Hasani, Dibra \\ Street, 372, Tirana, Albania, Tel: +3556/Fax: \\ $+35542363644$ \\ E-mail: eqeremhasani@yahoo.com \\ Received: 15-Jun-2013; Revised: 18-Aug- \\ 2013; Accepted: 20-Aug-2013; Online first: \\ 30-Sep-2013 \\ Copyright: $\odot 2013$ Hasani E. This is an open- \\ access article distributed under the terms of \\ the Creative Commons Attribution License, \\ which permits unrestricted use, distribution, \\ and reprodion in \\ Competing Interests: The authors have \\ declared that no competing interests exist.
}

\begin{abstract}
Aim: Aim of the study was the evaluation of the effect of dual blockade of the renin-angiotensin system (RAS) on proteinuria.

Material and Methods: Sixty patients, included in the study, were treated with angiotensinconverting enzyme inhibitor and angiotensin receptor blocker for a period of 3 months.

Results: The dual blockade of RAS resulted with decrease of proteinuria, a slight increase of serum creatinine and was not associated with a lowering of blood pressure.

Conclusion: Combined therapy with ACE-I and ARB results in a more complete blockade of the RAS than monotherapy. In proteinuric nephropathies it reduces significantly baseline proteinuria.
\end{abstract}

\section{Introduction}

The renin-angiotensin system plays a fundamental role in the maintenance and regulation of the extracellular fluid volume and blood pressure [1]. Angiotensin-converting enzyme (ACE) inhibitors and angiotensin II receptor blockers (ARB) are widely used in the treatment of hypertension, chronic kidney disease, and heart failure [2,3]. Despite its potential advantages, combination therapy with an ACE inhibitor and an ARB is not without risks. Significant decline in renal function is a rare but possible adverse effect of this drug combination. A more frequent adverse effect is a slight reduction in glomerular filtration rate (GFR), also hyperkalemia. Acute compromise of renal function was observed in a child after coadministration of lisinopril and losartan [4].
Both ACE-I and ARB impede the progressive deterioration in renal function, which underscores renal injury, particularly in patients with diabetic nephropathy [5-7]. The renoprotective effects of these drugs, in part, relates to their ability to reduce proteinuria $[8,9]$. It was just a matter of time before ACE-I and ARB were given together as combination therapy, due to evidence suggesting that these agents are complementary in their actions. The studies of combination therapy in proteinuric chronic kidney disease (CKD) have proven interesting data for their antiproteinuric and renoprotective efficassity [10-14].

The aim of the present study was the evaluation of the effect of dual blockade of reninangiotensin system on proteinuria in non-diabetic patients. 


\section{Materials and Methods}

Sixty non-diabetic patients with glomerular and intersticial disease were included in a prospective controlled study, with primary outcome the measure of proteinuria. The study had been approved by the Ethic Committee. At baseline 24 hour proteinuria was measured, as well as serum creatinine $(\mathrm{SCr})$ and GFR, measured by Cockcroft-Gault formula, seric sodium, potassium and blood pressure (BP); at baseline clinic blood pressure was $168 \pm 25.8 / 81 \pm$ $1.1 \mathrm{mmHg}$, SCr was $1.39 \pm 0.4 \mathrm{mg} / \mathrm{dl}$, seric sodium $141 \pm 3.5 \mathrm{mmol} / \mathrm{l}$, seric potassium $4.2 \pm 0.5 \mathrm{mmol} / \mathrm{l}$, and urinary proteinuria was $3.1 \pm 1.5 \mathrm{~g} /$ day. After the completion of the baseline exams, an ACE-I (enalapril $20 \mathrm{mg} /$ day) or an ARB (valsartan $80 \mathrm{mg} /$ day) was given for a period of 3 months; at the end of this period a repeat of all exams was done, and the combined treatment with ACE-I+ARB was started and continued for a further 3 months period, and at the end all the exams were repeated. All variables are presented as mean \pm standard deviation. Differences were considered significant at the $p<0.05$ levels. We used paired $t$ tests (which account for the same patients providing data for both treatment groups) to determine the effects of treatment.

\section{Results}

From 60 patients, 25 were females and 35 were males, with mean age $35.3 \pm 4.7$ (range: $35-70$ years-old) (Table 1).

Table 1: Patients' demographics and baseline data.

\begin{tabular}{cc}
\hline \hline Demographic variable & Total number of patients \\
\hline $\mathrm{N}$ & 60 \\
Sex $(\mathrm{M} / \mathrm{F})$ & $35 / 25$ \\
Age $($ years $)$ & $35.3 \pm 4.7(35-70)$ \\
Weight $(\mathrm{kg})$ & $64.2 \pm 6.7(54-96)$ \\
Height $(\mathrm{cm})$ & $162.7 \pm 7.4(154-189)$ \\
\hline
\end{tabular}

Monotherapy with ACE-I or ARB resulted in a non significant change of blood pressure, while seric level of potassium and sodium, Scr and GFR were not changed significantly. The 24 hour proteinuria decreased in both groups, but this was not significant. The combined treatment with ACE-I+ARB resulted in a significant reduction of proteinuria $(2.1 \pm 0.5 \mathrm{~g} /$ day vs. $3.1 \pm 1.5 \mathrm{~g} /$ day at baseline, $\mathrm{P}<0.01)$. The renal function was not significantly altered ( $\mathrm{SCr}$ increased not significantly to $1.5 \pm 0.16 \mathrm{mg} / \mathrm{dl} \quad(P=0.06)$, while seric level of potassium remained unchanged. The values of systolic and diastolic blood pressure were reduced but not significantly (Table 2 ).

\section{Discussion}

This study shows that ACE-I and ARB are effective and well-tolerated antihypertensive agents. Although not all patients who are treated with ACEI or
ARB show a clear antiproteinuric response [15], our data show efficacy of enalapril and valsartan as regard the decrease of proteinuria from the baseline values. The results of a limited number of studies support the notion that additive antihypertensive, cardioprotective, and antiproteinuric effects may be obtained when ACE-I and ARB are combined [16].

Table 2: Comparison of clinical and biochemical parameters.

\begin{tabular}{|c|c|c|c|c|c|}
\hline & \multicolumn{5}{|c|}{ After 3 months of treatment } \\
\hline & $\begin{array}{c}\text { Baseline } \\
\text { values }\end{array}$ & $\begin{array}{c}\text { Group with } \\
\text { ACE-I (30 } \\
\text { patients) }\end{array}$ & $\begin{array}{c}\text { Group with } \\
\text { ARB (30 } \\
\text { patients) }\end{array}$ & $\begin{array}{c}\text { ACE- } \\
\text { I+ARB } \\
\text { After } 6 \\
\text { months of } \\
\text { treatment }\end{array}$ & $\mathrm{p}$ \\
\hline $\begin{array}{l}\text { SBP } \\
(\mathrm{mmHg})\end{array}$ & $164 \pm 20.8$ & $160 \pm 23.7$ & $159 \pm 22.6$ & $142 \pm 13$ & NS \\
\hline $\begin{array}{l}\text { DBP } \\
(\mathrm{mmHg})\end{array}$ & $81 \pm 10.1$ & $79 \pm 10$ & $78 \pm 9.8$ & $76.7 \pm 6.2$ & NS \\
\hline $\mathrm{SCr}(\mathrm{mg} / \mathrm{dl})$ & $1.39 \pm 0.4$ & $1.39 \pm 0.9$ & $1.41 \pm 0.6$ & $1.5 \pm 0.16$ & NS \\
\hline $\begin{array}{l}\text { GFR } \\
\text { (ml/min) } \\
\text { Seric level }\end{array}$ & $82 \pm 9.2$ & $80 \pm 8.1$ & $81 \pm 6.9$ & $77.3 \pm 8.1$ & NS \\
\hline $\begin{array}{l}\text { of sodium } \\
\text { (mmol/l) } \\
\text { Proteinuria }\end{array}$ & $141 \pm 3.5$ & $142 \pm 2.6$ & $141.6 \pm 2.9$ & $140.8 \pm 3.6$ & NS \\
\hline $\begin{array}{l}\text { ( } 24 \text { hour) } \\
(\mathrm{g} / \mathrm{dl}) \\
\text { Seric level } \\
\text { of }\end{array}$ & $3.1 \pm 1.5$ & $2.8 \pm 0.7$ & $2.7 \pm 0.6$ & $2.1 \pm 0.5$ & 0.001 \\
\hline $\begin{array}{l}\text { potassium } \\
(\mathrm{mmol} / \mathrm{l})\end{array}$ & $4.2 \pm 0.5$ & $4.3 \pm 0.2$ & $4.2 \pm 0.9$ & $4.3 \pm 0.6$ & NS \\
\hline
\end{tabular}

creatinine; GFR-glomerular filtration rate

In chronic proteinuric non-diabetic nephropathies, most studies have shown a superior effect of the combination of ACE-I and ARB on proteinuria reduction in comparison with single therapy with ACE-I or ARB [8]. In our study, the dual blockade of renin-angiotensin system resulted in a decrease of proteinuria, although with a slight increase of serum creatinine due to hemodynamic effects of both these drugs, but without hyperkalemia. In our study the values of systolic and diastolic blood pressure were reduced but not significantly, this probably for the reason of a regular sodium diet. Recently, Slagman et al. reported that dietary sodium restriction to a level recommended in guidelines was more effective than dual blockade for reduction of proteinuria and blood pressure in non-diabetic nephropathy [17]. However, the results of recently published ONTARGET study has shown that combination of the two drugs (ACE-I and ARB) has not shown benefits in renal outcomes. The decision whether to initiate dual RAS blockade for an individual patient, therefore requires careful assessment of their risk of renal progression [18].

Our findings support the effects on protenuria of combined therapy with ACE-I and ARB. Further works would need to determine more accurate information of the changes in the GFR, BP under the influence of this applied therapy.

Conclusion: Combined therapy with ACE-I and ARB results in a more complete blockade of the RAS than monotherapy. In proteinuric nephropathies it reduces significantly baseline proteinuria. 


\section{References}

1. Elliott WJ: Therapeutic trials comparing angiotensin converting enzyme inhibitors and angiotensin II receptor blockers. Curr Hypertens Rep. 2000; 2:402-411.

2. Izzo JL Jr, Weir MR. Angiotensin-converting enzyme inhibitors. J Clin Hypertens (Greenwich) 2011; 13:667.

3. Taylor AA, Siragy H, Nesbitt S. Angiotensin receptor blockers: pharmacology, efficacy, and safety. J Clin Hypertens (Greenwich) 2011; 13:677.

4. Hanevold CD. Acute renal failure during lisinopril and losartan therapy for proteinuria. Pharmacotherapy. 2006; 26:13481351.

5. Brenner BM, Cooper ME, de Zeeuw D, et al: Effects of losartan on renal and cardiovascular outcomes in patients with type 2 diabetes and nephropathy. N Engl J Med. 2001; 345:861-869.

6. Lewis EJ, Hunsicker LG, Clarke WR, et al. Renoprotective effect of the angiotensin-receptor antagonist irbesartan in patients with nephropathy due to type 2 diabetes. $\mathrm{N}$ Engl $\mathrm{J}$ Med. 2001; 345:851-860.

7. Lewis EJ, Hunsicker LG, Bain RP, et al. The effect of angiotensinconverting-enzyme inhibition on diabetic nephropathy. The Collaborative Study Group. N Engl J Med. 1993; 329:1456-1462.

8. Kunz R, Friedrich C, Wolbers M, Mann JF. Meta-analysis effect of monotherapy and combination therapy with inhibitors of the renin angiotensin system on proteinuria in renal disease. Ann Intern Med. 2008; 148:30-48.

9. Keane WF, Brenner BM, de Zeeuw D, et al. The risk of developing end-stage renal disease in patients with type 2 diabetes and nephropathy: the RENAAL study. Kidney Int. 2003; 63:1499-1507.

10. Andersen $\mathrm{NH}$, Mogensen $\mathrm{CE}$. Angiotensin-converting enzyme inhibitors and angiotensin II receptor blockers: evidence for and against the combination in the treatment of hypertension and proteinuria. Curr Hypertens Rep. 2002; 4:394-402.

11. Russo D, Pisani A, Balletta MM, et al. Additive antiproteinuric effect of converting-enzyme inhibitor and losartan in normotensive patients with IgA nephropathy. Am J Kidney Dis. 1999; 33:851-856.

12. Russo D, Minutolo R, Pisani A, et al. Coadministration of losartan and enalapril exerts additive antiproteinuric effect in IgA nephropathy. Am J Kidney Dis. 2001; 38:18-25.

13. Reddan DN, Owen WF Jr. IgA nephropathy and inhibitors of the renin angiotensin system: is reduction in proteinuria adequate proof of efficacy? Am J Kidney Dis. 2001; 38:182185.

14. Ruilope LM, Aldigier JC, Ponticelli C, et al. Safety of the combination of valsartan and benazepril in patients with chronic renal disease. European Group for the Investigation of Valsartan in Chronic Renal Disease. J Hypertens. 2000; 18:8995.

15. Hollenberg NK, Fisher ND, Price DA. Pathways for angiotensin II generation in intact human tissue. Evidence from comparative pharmacological interruption of the renin system. Hypertension 2000; 32:387-392.

16. McLaughlin K, Jardine AG. Angiotensin converting enzyme inhibitors and angiotensin receptor (AT1) antagonists: either or both for primary renal disease? Nephrol Dial Transplant. 1999; 14:25-28.

17. Slagman MCJ, Waanders F, Hemmelder $\mathrm{MH}$ et al. Moderate dietary sodium restriction added to angiotensin converting enzyme inhibition compared with dual blockade in lowering proteinuria and blood pressure: Randomised controlled trial BMJ. 2011; 343:d4366 doi: 10.1136/bmj.d4366
18. Więcek A, Nieszporek T, Zarzecki M. Dual blocade of the renin-angiotensin-aldosterone: does it always slow the progression of kidney disease? Przew Lek 2010; 2:40-45. 